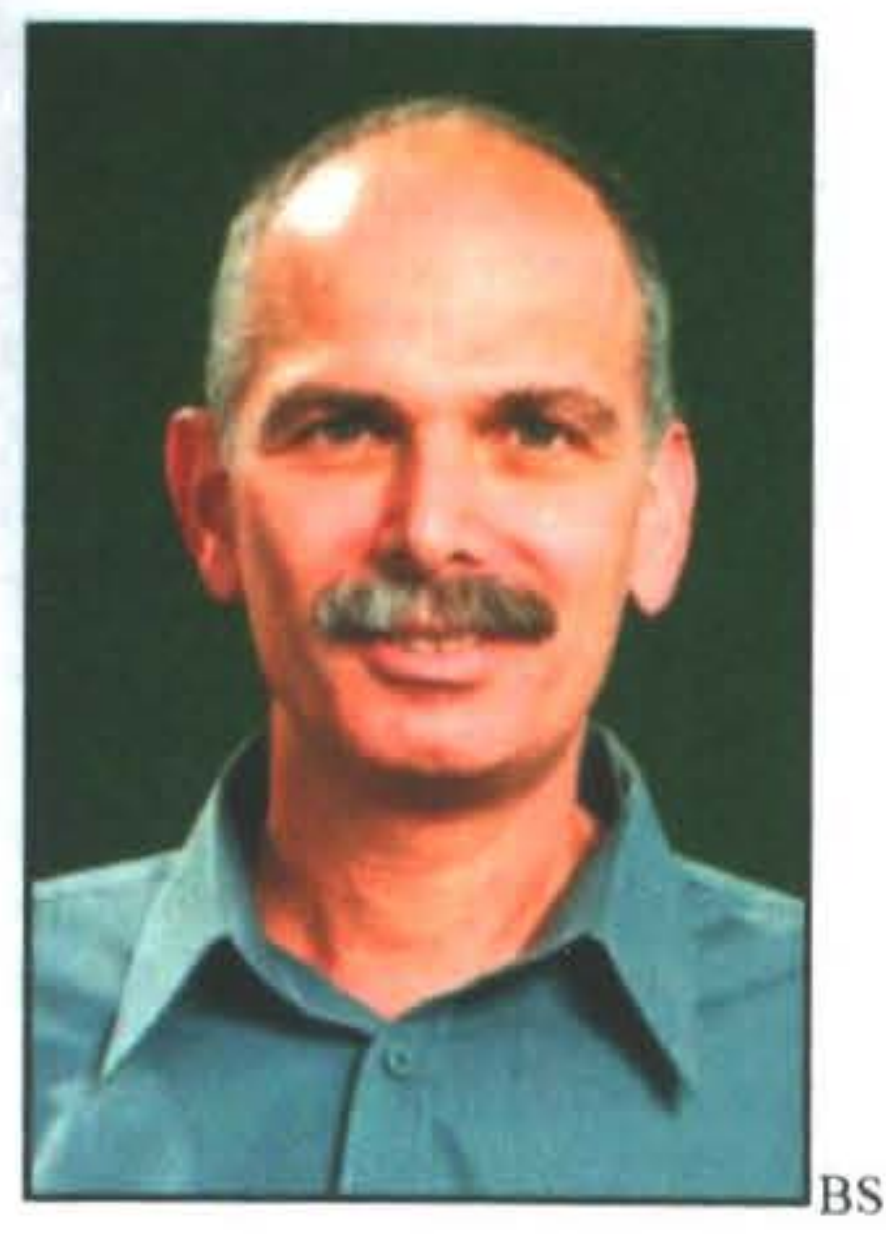

\title{
THE IMPACT OF THE EMPLOYMENT RELATIONS ACT 2000 ON COLLECTIVE BARGAINING
}

\author{
Brett Lineham, Louise Fawthorpe, \\ Boaz Shulruf, Stephen Blumenfeld and \\ Roopali Johri
}

Department of Labour

\begin{abstract}
This study carried out by the Department of Labour in 2007/08 aims to assess whether there have been any significant changes in the coverage of collective bargaining that can be atributed to the Employment Relations Act 2000 . The research draws on administrative data relating to union membership and collective bargaining coverage, as well as quantitative and qualitative data from employers, employees, union representatives and other employment relations stakeholders. The research shows that collective bargaining has yet to regain pre Employment Relations Act levels. Collective bargaining remains concentrated in the public sector, with low density in the private sector. The study concludes that the effects of the Act on collective bargaining are chiefly observed in the recovery of collective bargaining in the public sector, and the continued decline (in general) in the private sector. The research offers no indications that these patterns will change.
\end{abstract}

\section{Introduction}

In 1999 a Labour coalition government introduced the Employment Relations Act (the Act) with a key objective 'to build productive employment relationships through the promotion of mutual trust and confidence in all aspects of the employment environment and of the employment relationship. The Act explicitly sought to promote collective bargaining while maintaining protection of individual choice. Under the Act union membership remains voluntary but only union members may bargain for a collective agreement (Employment Relations Act 2000).

Research carried out in 2002/03 evaluating the extent to which the Act was meeting its objectives found that there had been no sustained growth in collective bargaining (Waldegrave et al 2003). Amendments to the Act in 2004 thus included stronger support for collective bargaining: since that time employers have been obliged to conclude a collective agreement, unless they have a genuine reason based on reasonable grounds not to (Employment Relations Amendment Act 2004).

The Department of Labour carried out this research in $2007 / 08$ to examine whether, after nearly a decade, the Act has had any significant effect on the coverage and content of collective bargaining. The mixed method study used material from Victoria University of Wellington's database of collective agreements, ' and administrative data relating to union membership, employment, and collective agreement coverage. This study also draws on results from a Department of Labour survey of employers, union representatives and employees associated with businesses in Auckland, Christchurch and Wellington. Qualitative research included interviews with employer and union national bodies, union representatives, employers, and employees, employment lawyers, professional advocates and Employment Relations Service mediators.

\section{Previous research}

While the Employment Contracts Act 1991 saw a marked decline in union membership, unions were experiencing reduced numbers prior to that Act. The Employment Relations Act was expected to reverse this trend because of several requirements the Act introduced: in particular, that unions registered under the Act had the sole entitlement to negotiate collective agreements, and that union representatives acquired rights of access to work places even when a union had no members in that work place (Waldegrave et al 2003). However, Boxall (2001) described a number of continuities in the Employment Relations Act carried over from the Employment Contracts Act which might be expected to temper any marked changes arising from the new legislation: these included voluntary unionism, a bargaining structure largely based around enterprises and workplaces, and personal grievance procedures being available to all employees.

International studies of declining unionisation also suggested that the Act would not precipitate a major increase in union membership. Lesch (2004) in his study of unionisation in OECD countries showed that factors such as membership practices, extension of collective agreements terms and conditions to non-union members, 
and the legislative framework providing a substitute for union negotiated protection acted against union membership. Further, decline in union density is an international trend (Visser 2006).

Reviewing the coverage of collective bargaining in New Zealand in 2006, McAndrew noted only modest growth, despite half a decade of encouraging legislation. Given that this was preceded by a decade of unsupportive legislation, McAndrew concluded that the situation of modest growth of collective bargaining seemed unlikely to change substantially as long as the legislation allows for, but does not mandate, collective bargaining. McAndrew suggested that what the legislation may actually do is not so much determine the spread or shrinkage of collective bargaining, but set the tone for the collective bargaining that does exist.

\section{Findings \& Discussion}

\section{Union membership}

Under the Act only union members may be covered by a collective agreement, therefore increasing the coverage of collective bargaining requires increased union membership across industry sectors. Since the Act was passed in 2000, union membership has increased by 17 percent to 373,327 members but has not grown outside of the traditionally strong areas of the public sector, and (in the private sector) in manufacturing, and the transport and storage industries. As the number of people employed has also increased since the Act, union density has been static over the last eight years at around 17 percent of the total employed labour force (see Table 1).

The research found, in line with international research, that there are multiple factors associated with individuals' decisions about joining a union. Key factors in whether people join a union are the presence of a union at the workplace and workers' belief that they need unions to protect conditions and wages. The selective benefits provided by unions are also important (for example, free representation in case of grievance). The influence of the workplace notwithstanding, the survey research found the key reason for employees not joining a union was satisfaction with their jobs. Employees not in unions also considered membership would not offer them sufficient benefits. A combination of factors contributed to this: terms and conditions were considered to be largely the same for unionised and non-unionised employees, there have been improvements in statutory minimum terms and conditions, work places now provide more support to resolve issues. and employees have better access to information and confidence in knowing their employment rights. Although the Act offers employees the choice of joining a union, because of the strong influence of workplace culture on union membership (and the prevalence of single enterprise bargaining), the research suggests that established patterns of union membership will not change significantly.

\section{Collective agreement coverage}

Since the Act was passed, both the absolute number and the proportion of all people employed covered by collective agreements has declined (see Table 2). This decline has been uneven across sectors, with the ratio of public to private sector coverage increasing over the last eight years (in 2008 this ratio was 5.7:1). In the private sector, larger businesses are more likely to have employees covered by collective agreements: however, over three quarters of businesses in New Zealand employ less than 20 workers, ${ }^{2}$ and a majority of businesses across all industry groups have no employees on collective agreements (see Table 3).

Since 2003 the number of unionised workers has exceeded the number of workers covered by collective agreements: currently around 40,000 union members do not have access to a collective agreement in their workplace. While the passing on of collectively negotiated conditions remains an issue for some union members, union representatives interviewed considered that the major barrier to increasing collective bargaining now is the sheer number of worksites without unionised employees or collective agreements. ${ }^{3}$

\section{Types of collective}

Under the Act, single employer-single union agreements have remained the prevalent form of collective agreement. The proportion of workers covered by single employer collectives has remained at approximately three quarters of all collectivised workers over the last eight years, requiring about 2,500 agreements to be negotiated by unions with single employers.

One of the union responses to this environment of low union density in the private sector and the prevalence of single enterprise bargaining has been to pursue multi employer bargaining. Although resource intensive to pursue, unions consider that workers have greater bargaining power under multi employer rather than single employer collectives. Multi employer collective agreements (MECAs) also address some of unions' resourcing issues associated with the numerous small collectives that must currently be negotiated. The proportion of collectivised workers covered by MECAs has grown from 18 to 26 percent over the last eight years. However, MECAs exist largely in the public sector with nearly half of the core government collectivised workforce covered by a multi employer agreement but only nine percent of collectivised workers in the private sector.

The research suggests that although there may in some circumstances be bargaining efficiencies for employers from MECAs, in general employers do not want to be party to MECAs due, at least in part, to their desire to control conditions for their businesses locally. Notably, some (private sector) employees were not necessarily convinced of the benefits of MECAs either, as they were concerned about drawn out and acrimonious bargaining associated with multi employer negotiations and with losing conditions to accommodate additional employers. 
In addition to employer resistance, and resourcing constraints for unions, the Act does not prefer MECAs above other forms of collective agreements, thus the research provides no indications that the coverage of MECAs will increase. Therefore, unless union membership were to change dramatically, collective agreement coverage is unlikely to increase markedly either.

\section{Good faith provisions}

One of the ways in which the Act facilitates collective bargaining is through provisions requiring employers to bargain in good faith. This includes the obligation to conclude a collective agreement if a union initiates one. The research has shown that this provision has not been sufficient to increase collective bargaining due to low and uneven union density. While it is difficult to quantify other impacts of the good faith provisions (bargaining process agreements, union access to worksites and information disclosure), the research has shown that both unions and employers consider that the Act has contributed, through the good faith concept, to the development of a more constructive style of collective bargaining. Evolving management and union approaches to employment relations were also held to be a factor in this progression. Individuals' attitudes, knowledge and skills were considered to be the critical factors determining the type of bargaining experience people had.

\section{Content of agreements}

The research found no evidence that the content of collective agreements has changed under the Act. Both analysis of the conditions in collective agreements over time and the view of all groups of respondents in the research indicated that there had been very little change in the content of collective agreements - negotiations are concentrated on wages and hours now as they have been historically. Nor have there been marked improvements in conditions for collectivised workers under the Act, other than those brought about by changes to statutory minima.

\section{Disputes}

Although the experience of research respondents with the Mediation Service and the Employment Relations Authority was mixed, and observations of the Employment Court entirely negative, respondents regarded the principles of dispute resolution under the Act positively. Since the Act, few of the employment relations disputes dealt with by the Mediation Service, the Employment Relations Authority or the Employment Court have been about collective bargaining. It is not known whether the small number of collective bargaining disputes in the Employment Relations Authority and the Employment Court reflect a smooth bargaining process or a reluctance to engage with dispute resolution bodies. Work stoppages (an indicator of employment relations), which were decreasing prior to the Act, have continued (somewhat unevenly over the years) to decrease.

\section{Perceptions of costs and benefits of collective bargaining}

The research did not look at the economic costs and benefits of collective bargaining however the literature suggests that any such attempt would be inconclusive. Although the cost benefit of having a collectivised workforce has not been shown, the survey research found a positive association between employers' perceptions that collectivised workplaces are better for businesses and the proportion of employees covered by a collective. The corollary of this finding is that employers with no experience of a collectivised workforce hold negative views about collective bargaining despite their lack of experience with it. In the qualitative research employers, employer representatives and employment relations professionals had a common view of the costs or benefits of collective bargaining to employers: the extent to which it was a cost or benefit depended on the employers' circumstances: for larger employers who were willingly involved in collective bargaining it offered efficiencies that outweighed the costs involved.

The international literature suggests that it is not possible to generalise about the impact of unions on productivity levels The qualitative research provided limited indications of a 'partnership' approach to productivity through collective bargaining. Union organisers were more likely than employers to consider that where employees were unionised, productivity was increased. However, both union representatives and employers agreed that the impact of the Act on productivity could not be observed (although efforts to increase productivity occurred outside of as well as within collective bargaining).

\section{Conclusion}

The Employment Relations Act was thought to have had a positive effect on the process of bargaining but not the outcome, thus supporting McAndrew's earlier (2006) analysis that the Act sets the tone rather than determining the spread or shrinkage of collective bargaining. Overall the impacts of the Act on collective bargaining are chiefly observed in the recovery of collective bargaining in the public sector, and the continued decline (in general) in the private sector.

\section{Future research}

There is a need for more comprehensive union and union membership data: this would also contribute to a better understanding of potential union membership. Further analysis of the databases of collective agreements held by the Department of Labour and Victoria University could be carried out to address some of the questions that were not explored in this research, for example: providing some detail about those union members not covered by collective agreements exploring how extensive quasi multi employer collective agreements are (where conditions in single employer collectives are aligned as much as possible within industries) looking at the impacts for employees and employers associated with MECAs and with single enterprise unions. 
Table 1: Union membership 1989-2008

\begin{tabular}{ccccccc}
\hline Date & $\begin{array}{c}\text { Union } \\
\text { membership }\end{array}$ & $\begin{array}{c}\text { Number of } \\
\text { unions }\end{array}$ & Total employed & $\begin{array}{c}\text { Union density } \\
\begin{array}{c}\text { \% change in } \\
\text { union } \\
\text { membership }\end{array}\end{array} \begin{array}{c}\text { \% change in } \\
\text { total employed }\end{array}$ \\
\hline Sep-89 & 684,825 & 112 & $1,520,000$ & $45 \%$ & n/a & n/a \\
May-91 & 603,118 & 80 & $1,521,700$ & $40 \%$ & -11.9 & 0.1 \\
Dec-91 & 514,325 & 66 & $1,518,800$ & $34 \%$ & -14.7 & -0.2 \\
Dec-92 & 428,160 & 58 & $1,539,500$ & $28 \%$ & -16.8 & 1.4 \\
Dec-93 & 409,112 & 67 & $1,586,600$ & $26 \%$ & -4.4 & 3.1 \\
Dec-94 & 375,906 & 82 & $1,664,900$ & $23 \%$ & -8.1 & 4.9 \\
Dec-95 & 362,200 & 82 & $1,730,700$ & $21 \%$ & -3.6 & 4.0 \\
Dec-96 & 338,967 & 83 & $1,768,200$ & $19 \%$ & -6.4 & 2.2 \\
Dec-97 & 327,800 & 80 & $1,773,200$ & $18 \%$ & -3.3 & 0.3 \\
Dec-98 & 306,687 & 83 & $1,760,900$ & $17 \%$ & -6.4 & -0.7 \\
Dec-99 & 302,405 & 82 & $1,810,300$ & $17 \%$ & -1.4 & 2.8 \\
Dec-00 & 318,519 & 134 & $1,848,100$ & $17 \%$ & 5.3 & 2.1 \\
Mar-02 & 342,179 & 170 & $1,901,000$ & $18 \%$ & 7.4 & 2.9 \\
Mar-03 & 334,044 & 181 & $1,928,700$ & $17 \%$ & -2.4 & 1.9 \\
Mar-04 & 340,413 & 179 & $1,988,000$ & $17 \%$ & 1.9 & 3.1 \\
Mar-05 & 354,898 & 151 & $2,054,800$ & $17 \%$ & 4.3 & 3.4 \\
Mar-06 & 366,985 & 178 & $2,107,900$ & $17 \%$ & $18 \%$ & 2.7 \\
Mar-07 & 376,763 & 169 & $2,144,200$ & $17 \%$ & -0.9 & 2.6 \\
Mar-08 & 373,327 & 168 & $2,138,900$ & 1.7 & -0.2 \\
\hline
\end{tabular}

Sources: union membership figures 1989-2000 from May et al 2000 and 2002-2008 from Department of Labour union membership statistics; total employed figures from Household Labour Force Survey data 1989-2007 from Statistics NZ 2008. *Total number of people employed describes those people who are working as self-employed and/or as a wage and salary earner, ie, it is larger than the number of people who could potentially join a union or be covered by a collective agreement.

Table 2: Collective agreement coverage 2000-2008

\begin{tabular}{cccccc}
\hline $\begin{array}{c}\text { Year } \\
\text { (June) }\end{array}$ & $\begin{array}{c}\text { Number of } \\
\text { collective } \\
\text { agreements }\end{array}$ & $\begin{array}{c}\text { Total employee } \\
\text { coverage by } \\
\text { collective } \\
\text { agreements }\end{array}$ & $\begin{array}{c}\text { Total union } \\
\text { membership }\end{array}$ & $\begin{array}{c}\text { Total number of } \\
\text { people } \\
\text { employed } *\end{array}$ & $\begin{array}{c}\text { Proportion of people } \\
\text { employed covered by } \\
\text { collective agreements }\end{array}$ \\
\hline 1996 & No data & 403,000 & 338,967 & $1,747,300$ & $23 \%$ \\
1997 & No data & 416,000 & 327,800 & $1,758,900$ & $24 \%$ \\
1998 & No data & 418,700 & 306,687 & $1,741,500$ & $24 \%$ \\
1999 & No data & 421,400 & 302,405 & $1,764,600$ & $24 \%$ \\
2000 & 3,877 & 420,600 & 318,519 & $1,782,300$ & $24 \%$ \\
2001 & 3,260 & 391,400 & 319,660 & $1,840,300$ & $21 \%$ \\
2002 & 3,465 & 399,100 & 342,179 & $1,896,400$ & $21 \%$ \\
2003 & 2,477 & 329,300 & 334,044 & $1,931,800$ & $17 \%$ \\
2004 & 2,353 & 297,800 & 340,413 & $1,992,100$ & $15 \%$ \\
2005 & 2,593 & 300,700 & 354,898 & $2,052,600$ & $15 \%$ \\
2006 & 2,581 & 321,900 & 366,985 & $2,115,500$ & $15 \%$ \\
2007 & 2,512 & 309,900 & 376,763 & $2,148,100$ & $14 \%$ \\
2008 & 2,684 & 331,800 & 373,327 & $2,163,800$ & $15 \%$ \\
\hline
\end{tabular}

Sources: Union membership data from May et al 2001 and the Department of Labour; collective agreement data from Lafferty \& Kiely 2008; people employed data from Statistics NZ Household Labour Force Survey. 
Table 3: Collective employment agreements in the private sector by industry (2007)

\begin{tabular}{|c|c|c|c|c|c|c|c|}
\hline \multirow[t]{3}{*}{ Industry } & \multirow{3}{*}{$\begin{array}{l}\text { Number of } \\
\text { businesses }\end{array}$} & \multicolumn{6}{|c|}{ Proportion of employees covered by a collective agreement } \\
\hline & & Zero\% & $\begin{array}{c}10 \% \text { or } \\
\text { less }\end{array}$ & $\begin{array}{c}50 \% \text { or } \\
\text { less }\end{array}$ & $\begin{array}{c}90 \% \text { or } \\
\text { less }\end{array}$ & $\begin{array}{l}90 \text { to } \\
100 \%\end{array}$ & Unknown \\
\hline & & \multicolumn{6}{|c|}{ Percentage of all businesses } \\
\hline Agriculture, forestry and fishing & 3,060 & 73 & 0 & 2 & 2 & 14 & 9 \\
\hline Mining and quarrying & 96 & 67 & 3 & 8 & 6 & 15 & 2 \\
\hline Manufacturing & 5,349 & 60 & 3 & 8 & 8 & 17 & 5 \\
\hline Electricity, gas and water supply & 18 & 65 & 17 & 6 & 6 & 6 & 6 \\
\hline Construction & 3,609 & 66 & 2 & 4 & 2 & 18 & 8 \\
\hline Wholesale trade & 3,081 & 74 & 3 & 3 & 1 & 12 & 8 \\
\hline Retail trade & 5,772 & 69 & 2 & 2 & 1 & 19 & 7 \\
\hline Accommodation, cafes and restaurants & 3,360 & 64 & 3 & 0 & 4 & 13 & 16 \\
\hline Transport and storage & 1,530 & 67 & 3 & 6 & 6 & 16 & 1 \\
\hline Communication services & 132 & 69 & 5 & 2 & 2 & 18 & 4 \\
\hline Finance and insurance & 573 & 84 & 1 & 4 & 2 & 6 & 2 \\
\hline Property and business services & 5,118 & 82 & 2 & 1 & 1 & 10 & 4 \\
\hline Education & 606 & 74 & 4 & 1 & 0 & 13 & 8 \\
\hline Health and community services & 2,097 & 64 & 2 & 12 & 6 & 13 & 3 \\
\hline Cultural and recreational services & 597 & 62 & 5 & 2 & 5 & 22 & 5 \\
\hline Overall & 35,004 & 69 & 2 & 4 & 3 & 15 & 7 \\
\hline
\end{tabular}

Source: Statistics NZ Business Operation Survey 2007

\section{Notes}

1. Agreements received by Victoria University's Industrial Relations Centre are submitted on a voluntary basis, however the Centre considers that, although incomplete, their database covers the overwhelming majority of employees covered by collective agreements.

2. Statistics NZ Business Operations Survey 2007 data shows that of the 35,000 businesses with more than 5 employees, three quarters have between 6 and 19 employees.

3. Note that while the 2004 amendment to the Act made it a breach of good faith to pass on collectively negotiated terms and introduced a bargaining fee, union representatives considered this had made little difference to the extent or impact of pass on.

\section{References}

Boxall, P. (2001) Evaluating continuity and change in the Employment Relations Act 2000. NZJIR 26(1).

Lafferty, G., and Kiely, P. (2008) Employment agreements: bargaining trends and employment law update 2007/2008. Industrial Relations Centre, Victoria University of Wellington.

Lesch, H. (2004) Trade union density in international comparison. CESifo Forum 4/2004.

May, R., Walsh, P., Thickett, G. and Harbridge, R. (2001) Unions and Union Membership in New
Zealand: Annual Review for 2000. Industrial Relations Centre, Victoria University of Wellington.

McAndrew, I. (2006) Employers, unions and workplace partnerships in New Zealand. NZJER 31(3): 51-65.

Visser, J. (2006) Union Membership Statistics in 24 Countries. Federal Publications. Cornell University.

Waldegrave, T., Anderson, D. and Wong, K. (2003) Evaluation of the short-term impacts of the Employment Relations Act 2000. Department of Labour, Wellington.

\section{Authors}

Brett Lineham

Department of Labour

PO Box 3705

Wellington

Brett.Lineham@dol.govt.nz

Louise Fawthorpe

Department of Labour

PO Box 3705

Wellington

Louise.Fawthorpe@dol.govt.nz

Boaz Shulruf

Department of Labour

PO Box 3705

Wellington

Boaz.Shulruf@dol.govt.nz 
Stephen Blumenfeld

Senior Lecturer

HR Management and Industrial Relations

Victoria University of Wellington

P.O. Box 600

Wellington 6140

Stephen.Blumenfeld@vuw.ac.nz

Roopali Johri

Department of Labour

PO Box 3705

Wellington

Roopali.Johri@dol.govt.nz 